\title{
Biosaintifika
}

Journal of Biology \& Biology Education

http://journal.unnes.ac.id/nju/index.php/biosaintifika

\section{An Analysis of Partial DNA Sequence of Meisa1 Gene on Sweet and Bitter Cassavas (Manihot esculenta)}

\author{
${ }^{\square}$ Dewi Indriyani Roslim, Fitriyatun Nisa, Herman
}

DOI: 10.15294/biosaintifika.v8i1.5365

Department of Biology, Faculty of Mathematics and Natural Science, Universitas Riau, Indonesia

\section{History Article}

Received 7 January 2016 Approved 23 February 2016 Published 29 March 2016

\section{Keywords:} esculenta Crantz; Meisa1 gene; mutation; PCR
DNA sequence; Manihot

\begin{abstract}
Sweet and bitter taste on cassava tuber is affected by starch metabolisms. Meisa1 gene is a gene in cassava (Manihot esculenta) encoding isoamylase1 enzyme involved in starch metabolisms. This study aimed to analyze partial DNA sequences of $\mathrm{Mei}$ sa1 gene on sweet and bitter cassavas collected by Genetics Laboratory, Department Biology, Faculty of Mathematics and Natural Sciences, Riau University, Indonesia. Methods included total DNA extraction from fresh young leaves of cassava using CTAB buffer, polymerase chain reaction (PCR), electrophoresis, and sequencing. The obtained data were analyzed using MEGA software version 5 . The results showed that there were nucleotide variations in the intron region, not in the exon region. The variations were caused by the transition substitution mutation (35.39\%) and transversion substitution mutation (64.61\%). The genetic distance range between seven cassava genotypes was approximately $0 \%$ to $11 \%$. Partial DNA sequence variations of Meisal gene located in intron region were unable to cluster seven cassava genotypes separately into two groups based on tuber taste.
\end{abstract}

\section{How to Cite}

Roslim, D., Nisa, F., \& Herman, H. (2016). An Analysis of Partial DNA Sequence of Meisal Gene on Sweet and Bitter Cassavas (Manihot esculenta). Biosaintifika: Journal of Biology \& Biology Education, 8(1) 105-112.

(C) 2016 Semarang State University

$\bowtie$ Correspondence Author:

p-ISSN 2085-191X

Kampus Bina Widya, J1. HR Soebrantas, Panam, Pekanbaru 28293, Riau e-ISSN 2338-7610

E-mail: dewiindriyaniroslim@gmail.com 


\section{INTRODUCTION}

Cassava (Manihot esculenta) is one of carbohydrate-rich tuber producer plants which can be consumed by human as a staple food (Lancaster \& Brooks 1983; El-Sharkawy 2003). Cassava is very good to be cultivated because it is resistant to drought (El-Sharkawy 1993) and can grow well in acidic soil that is poor in nutrients and does not require much labor, time, and costs during the planting until harvest compared to other crops (Scott et al. 2002; Howeler 2006). Also, cassava can be used for many purposes, such as animal feed, the raw material for various starch based industries such as cosmetics, flour, baby food, biopolymer, and bioenergy (Tonukari 2004; El-Sharkawy 2003; Nassar \& Ortiz 2010; Nuwamanya et al. 2011; Marx \& Nquma 2013). For human or animal consumptions, cyanogenic glucoside in cassava tuber and leaf must be lower, i.e. below $40 \mathrm{mg} / \mathrm{kg}$ tuber fresh weight (Irtwange \& Achimba 2009) because the cyanogenic glucoside content that is higher than the provisions can cause bitterness to the tuber and those who consume it may be poisoned and may even die. It would be better if the starch content is higher than the cyanogenic glucoside so that the tuber is not bitter and poisonous. The starch content and the quality in cassava tuber are important characteristics in various industries and cassava breeding program (Jennings \& Iglesias 2002; Mohamed et al. 2009).

A few cassava genotypes from Riau Province, Indonesia, can produce tuber which is sweet, not sweet and bitter. The cassava which produces sweet or not bitter tuber is called sweet cassava genotype, whereas the one which produces bitter tuber is called bitter cassava genotype. Variegata, Sayur, Roti, and Hijau cassava genotypes belong to a sweet cassava genotype group, while Menggalo, Keriting, and Lurus belong to a bitter cassava genotype group (Roslim et al. 2015a; Roslim et al. 2016). McMahon et al. (1995) and Wilson \& Dufour (2002) argue that the difference between sweet and bitter cassava lie in the starch and the cyanogenic glucoside contained in tuber or whole plant. The starch content which is higher than the cyanogenic glucoside content causes the tuber to be not bitter, or it tends to be sweet or the reverse.

Starch is a reserved carbohydrate in plants which is stored in tuber as a granule or semicrystalline granule in cassava plant. It consists of two glucose polymers; that is, amylose and amylopectin, and their monomer is in the form of $\alpha$-glucan. Glucan composition varies from variety to variety and from species to species in plants (Patron
\& Keeling 2005). The starch quality very much depends on amylose composition. About $60 \%$ to $90 \%$ of starch in plants is in the form of amylopectin. The amylopectin among plants varies in terms of granule, composition, and structure (Han et al. 2007; Valdez et al. 2008; Hannah et al. 2008; Keeling et al. 2010).

Starch metabolism involves various enzymes, among others ADP-glucose phosphorylase, starch synthase, starch branching, and starch debranching enzymes. One of the starch debranching enzymes is isoamylase that functions to hydrolize $\alpha-1,6$ brach points in amylopectin, glycogen, and proto glycogen to produce glucose (Nakamura et al. 1996). Isoamylase enzyme is classified into of three types, i.e. ISA1, ISA2, and ISA 3 and each type respectively has a specific function in starch metabolism (Sundberg et al. 2013; Kang et al. 2013). Genes encoding isoamylase-type 1 (ISA1) have been cloned and characterized from some of crop species (Sun et al. 1999; Kim et al. 2005; Takashima et al. 2007; Beyene et al. 2010).

Complement DNA (cDNA) encoding ISA1 from cassava (better known as Meisal gen) has been cloned and characterized by Beyene et al. (2010) and may reach $764 \mathrm{bp}$ in length. Meisa1 gene begins to be expressed when the plant is three months old after planting and then the expression is stoped when the plant is six months old, and its highest level of expression occurs in tuber followed by the stem, leaf, and petiole. It indicates that Meisal gene has a major role in root differentiation to become storage root or tuber and early initiation of starch granule formation (Beyene et al. 2010).

The research on DNA sequence of Meisa1 gene in sweet and bitter cassava genotypes from Riau Province, Indonesia was conducted by Roslim et al. (2015b) using Variegata as a sweet cassava genotype and Keriting as a bitter cassava genotype. The findings showed that DNA sequence of Meisal gene in cassavas had some differences. The clustering analysis described that the three Variegata plants being studied formed one separate group from the three Keriting plants. Based on this preliminary study, it was necessary to study the DNA sequence of Meisa1 gene on other sweet and bitter cassava genotypes for verification of the ability of DNA sequence of Meisa1 gene to differenciate sweet and bitter cassava genotypes.

\section{METHODS}

\section{Plant Materials}

The plant materials used in this research were sweet cassava genotypes (Variegata, Roti, 
Hijau, and Sayur) and bitter cassava genotypes (Menggalo, Keriting, and Lurus) the collection of the Genetic Laboratory, Department of Biology, Faculty of Mathematics and Natural Science, Universitas Riau, Indonesia.

\section{Total DNA Extraction}

The DNA total was isolated from fresh young leaves of cassava using CTAB buffer (Saghai-Maroof et al. 1984). As many as $200 \mathrm{mg}$ leaves were cut with a clean scissor then were grinded using mortar and pestle and liquid nitrogen. Then the powder was put into a $50 \mathrm{ml}$ sterile tube and added with 1 volume of CTAB buffer. The mixture was then incubated in a water bath at $65^{\circ} \mathrm{C}$ for 1 hour, and then it was cooled at room temperature. After that, 1 volume of chloroform was added, and the mixture was inverted until it was homogenized for 10 minutes. Then, it was centrifuged at $4000 \mathrm{rpm}$ for 15 minutes. The liquid phase or supernatant was transferred to a 1.5 $\mathrm{ml}$ sterile tube, then was added with 1 volume of isopropanol and was inverted to form white clumps of tangled DNA molecules, and then it was centrifuged at $4000 \mathrm{rpm}$ for 10 minutes. The liquid phase was discharged and the pellet DNA formed was dried at $37^{\circ} \mathrm{C}$. Once it was dry, it was added with $500 \mu 1 \mathrm{TE}$ buffer and then was incubated at $37^{\circ} \mathrm{C}$ for one night. After that, it was added with $200 \mu \mathrm{TE}$ buffer to increase the DNA solution volume, and then it was added with 700 $\mu \mathrm{l}$ phenol. The mixture was inverted slowly for 10 minutes and was centrifuged at $4000 \mathrm{rpm}$ for 10 minutes.

The liquid phase on the top which contained DNA solution was transferred into a new $1.5 \mathrm{ml}$ sterile tube, and then it was added with 1 volume of isopropanol. The tube was inverted to form white clumps of tangled DNA molecules. The tube was centrifuged again at $4000 \mathrm{rpm}$ for 10 minutes. The pellet DNA was dried at $37^{\circ} \mathrm{C}$, and then the precipitated DNA was rinsed with $70 \%$ ethanol and was dissolved again with 100 $\mu 1 \mathrm{TE}$ buffer. The DNA stock solution was stored at $-20{ }^{\circ} \mathrm{C}$ while the working DNA solution was stored in the refrigerator at $4{ }^{\circ} \mathrm{C}$ for further analysis.

\section{Amplification with Polymerase Chain Reac- tion (PCR) technique}

The PCR process was conducted using a $50 \mu 1$ PCR reaction containing $1 \mathrm{x}$ PCR buffer; $100 \mathrm{mM} \mathrm{dNTP}_{\mathrm{s}} ; 0.2 \mu \mathrm{M}$ forward primer 5 '- AGC ATC ATT AAG GCA CAC CT-3'; $0.2 \mu \mathrm{M}$ reverse primer 5'- ATG CTT TGA ATT CAC CCT GT -3'; 1 Unit Taq DNA polymerase (Thermo
Scientific), $\mathrm{dH}_{2} \mathrm{O}$, and $100 \mathrm{ng}$ total DNA of cassava. The PCR analysis was performed with the following conditions: 5 minutes at $94{ }^{\circ} \mathrm{C}$ for 1 cycle followed by 1 minute at $94^{\circ} \mathrm{C}, 1$ minute at $50^{\circ} \mathrm{C}$, 1 minute at $72{ }^{\circ} \mathrm{C}$ for 35 cycles and ended with 1 cycle of post-PCR for 10 minutes at $72{ }^{\circ} \mathrm{C}$.

\section{Electrophoresis}

Electrophoresis was aimed to determine the results of DNA extraction and also the PCR process. Electrophoresis was performed using $1.2 \%$ agarose gel in $1 \mathrm{xTBE}$ buffer (Tris-borat EDTA pH 8) at 65 volts for 30 minutes. The gel was soaked in ethidium bromide solution to stain the DNA and then the DNA bands were observed under the UV lamp transillumination (WiseUv WUV-M20, Daihan Scientific) and were documented using a digital camera (Olympus SP-500 UZ).

\section{DNA Sequencing}

DNA sequencing is the process to determine the precise order of nucleotides within a DNA molecule. In this research, PCR products were then sent to PT Genetika Science in Jakarta to be purified and sequenced at $1^{\text {st }}$ Base in Malaysia in two directions using PCR primer.

\section{Data Analysis}

The obtained DNA sequences obtained were analyzed using MEGA software version 6.06 (Build\#: 6140226) (Molecular Evolutionary Genetics Analysis) and BLASTn program (Basic Local Alignment Search Tool) at http://www.ncbi. nlm.nih.gov/ BLAST (Altschul et al. 1997).

\section{RESULTS AND DISCUSSION}

\section{Total DNA Molecules and Partial DNA Frag- ment of Meisa1 Gene}

In this research, the quality and quantity of total DNA molecules and PCR products were determined using electrophoresis technique (Figure 1). Electrophoresis is a technique to separate charged particles on a porous matrix under electric fields with the principal that is negative charged DNA molecules migration on a porous matrix, such as agarose gel, from negative pole (anion) towards the positive pole (cation). The DNA movement in a porous matrix depends on the gel concentration, voltage, buffer ionic strength, and DNA conformation (Lee \& Bahaman 2010). The total DNA molecules obtained from seven cassava genotypes were sufficient intacts which were characterized by thick DNA band sizing above $10000 \mathrm{bp}$. Their concentrations were 
approximately $100-500 \mathrm{ng} / \mu \mathrm{l}$ and they could be used as a template in PCR (Figure 1A).

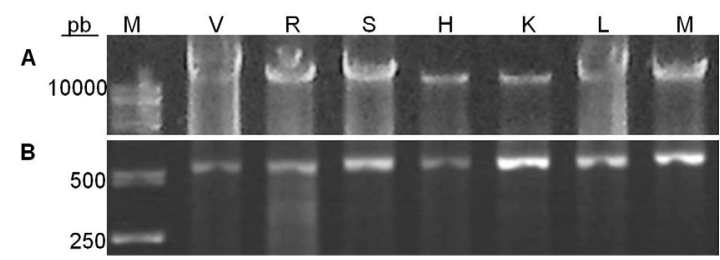

Figure 1. (A) Total DNA molecules and (B) partial DNA fragment of Meisa1 gene on seven cassava genotypes which were electroporated using $1.2 \%$ agarose gel in $1 \mathrm{xTBE}$ buffer. (M) $1 \mathrm{~kb}$ DNA Ladder, (V) Variegata, (R) Roti, (S) Sayur, (H) Hijau, (K) Keriting, (L) Lurus, and (M) Menggalo.

Partial DNA fragment of Meisa1 gene sizing $534 \mathrm{bp}$ had been successfully obtained from seven cassava genotypes observed in this study (Figure 1B). The thickness of the DNA fragments was different among them. However, the DNA fragments were sufficient for the sequencing process requirement. The thickness of the DNA fragments was also found by Nugraha et al. (2014), but it did not affect the results because the thickness of the DNA fragments was not related to DNA sequence analysis. The thickness of the DNA fragments associated with the expression analysis at the level of mRNA transcripts or proteins (Beyene, 2011; Hu et al., 2015).

\section{Analysis of Partial DNA Sequences of Meisa1 Gene}

The DNA sequencing was conducted in this study to determine the precise order of nucleotides within DNA fragments of Meisa1 gene on seven cassava genotypes. The alignment using BLASTn program showed that the DNA sequences was accurately the part of Meisa1 gene (Accession: GU229751.1) which could be seen in every parameter, especially the E-value and Ident (Table 1).

The Table 1 shows that the indent value is high, close to an absolute percentage, i.e. $96 \%$, and the E-value is low (2e-19). These results sho- wed the high similarity of nucleotide sequence observed with Meisal gene in the database rather than with Rcisal gene. In addition, the data was accurate.

Ident value is a percentage of accuracy of alignment or a percentage of similarity of the aligned sequences, the larger its value, the higher the aligned sequence similarity. E-value is a probability of an alignment error statistically; the smaller its value, the more accurate its data. The query cover is a the percentage of query sequences used in the analysis or the percentage of similar sequences with sequences in the database or sequences being compared (Fassler \& Cooper 2008).

In this study, it was discovered that the query cover value was very small, i.e. $13 \%$ because of the nucleotide sequences observed were the DNA molecules of Meisal gene while the sequences in the database were the cDNA molecules of Meisa1 gene. Furthermore, cDNA molecules came from the reverse transcription of mRNA so that it only comprised exons sequences, whereas DNA molecules consisted of introns and exons sequences (Griffiths et al. 2008). Therefore, the sequences in this study that aligned with database sequences were only exon sequences which were about 66 bp while the rest were the intron sequences of Meisal gene.

The alignment analysis also showed that the nucleotide sequences of the partial DNA sequences of Meisa1 gene on the seven cassava had a high similarity ( $87 \%$ ) with the mRNA of isoamylase gene in the Ricinus communis (Rcisal gene). This was according to research conducted by Beyene et al. (2010) which stated that Meisal gene had high similarity to Rcisal genes in jatropha (Ricinus communis) but not with another isoform (ISA2 and ISA3) of the isoamylase gene (Beyene et al. 2010). Possibly it happened because cassava species are closely related to jatropha, and they come from the same family, Euphorbiaceae.

Furthermore, the multiple alignment analysis showed that there were a few nucleotides differences between those cassavas observed. Those differences were not observed to lie in exon region

Table 1. Nucleotide alignment results of partial DNA sequences of Meisa1 gene on seven cassava genotypes using BLASTn program.

\begin{tabular}{lcccccc}
\hline Description & $\begin{array}{c}\text { Max } \\
\text { score }\end{array}$ & $\begin{array}{c}\text { Total } \\
\text { score. }\end{array}$ & $\begin{array}{c}\text { Query } \\
\text { cover }\end{array}$ & $\begin{array}{c}\text { E } \\
\text { value }\end{array}$ & Ident. & Accession \\
\hline $\begin{array}{l}\text { Manihot esculenta isoamylase (Meisa1) } \\
\text { mRNA, partial cds }\end{array}$ & 107 & 107 & $13 \%$ & $2 \mathrm{e}-19$ & $96 \%$ & GU229751.1 \\
$\begin{array}{l}\text { Ricinus communis isoamylase } \\
\text { sal), putative, mRNA }\end{array}$ & 82.4 & 82.4 & $13 \%$ & $8 \mathrm{e}-12$ & $87 \%$ & XM_002529854.1 \\
\hline
\end{tabular}


but in intron region. The nucleotide differences or variations were caused by substitution mutation, either transition or transversion substitutions or deletion mutation (Table 2, Figure 2).

The total percentage of transition substitution mutation in this study was $35.39 \%$ less than the total percentage of transversion substitution mutation $(64.61 \%)$ as shown in Table 2. Transition substitution mutation is a change in nucleotide from purine to purine $(A \ll G)$ or pyrimidine to pyrimidine $(\mathrm{T} \ll \mathrm{C})$, while transversion substitution mutation is a change in nucleotide from purine to pyrimidine, vice versa (Griffiths et al. 2008). According to Graur (2003), mutation does not occur randomly in the genome and it rarely occurs in exons or binding sites of regulator proteins. Moreover, not all mutation types occur with the same frequency. In nuclear animal DNA, the transition substitution mutation more frequently occurred
(60\%-70\%) compared to the others. The transition substitution mutation in random mutation was only $33 \%$. The ratio of transition to transversion mutation in animal mitochondrial genomes was 20:1.

Table 2. Transversion and transition substitution mutation matrix of partial DNA sequences of Meisa1 gene on seven cassava genotypes calculated using Tamura \& Nei (1993) model.

\begin{tabular}{lllll}
\hline Nucleotide & A & T/U & C & G \\
\hline A & - & 9.31 & 6.20 & 7.15 \\
T/U & 12.17 & - & 3.77 & 4.62 \\
$\mathrm{C}$ & 12.17 & 5.65 & - & 4.62 \\
G & $\mathbf{1 8 . 8 2}$ & 9.31 & 6.20 & - \\
\hline
\end{tabular}

Notes: Figures typed in bold and italic shows transition substitution, and the figures upright shows transversion substitution

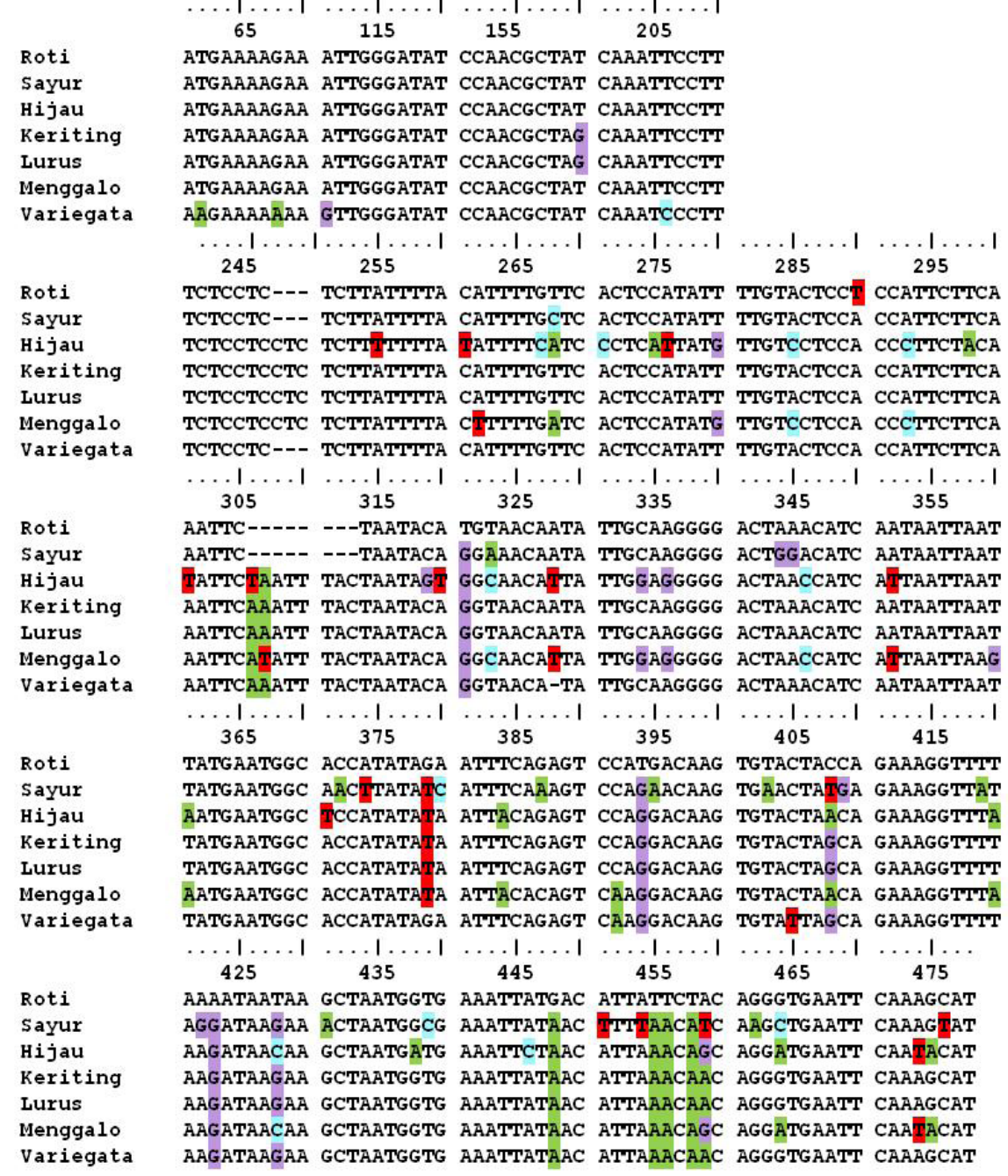

Figure 2. Mutation position in intron region of partial DNA sequences of Meisal gene on seven cassava genotypes. 
A gene in eukaryotic organisms usually consists of a few exons regions where each exon of a gene encodes part of a protein and also a few introns regions of which each separates the exons. Both exons and introns to be transcribed to produce pre-mRNA and this pre-mRNA will be modified after the transcription in order to produce mature mRNA which only consists of exons regions. The mature mRNA to be translated into protein or enzyme depends on the gene (Griffith et al. 2008).

In intron region observed, nucleotide composition average of $\mathrm{G}+\mathrm{C}$ in intron was less $(31.2$ $\%)$ than $\mathrm{A}+\mathrm{T}(68.8 \%)$ (Table 3). The result accorded with Amit et al. (2012) who reported that the $\mathrm{G}+\mathrm{C}$ content in plants introns regions were less than in its exons and related to splicing efficiency.

Table 3. Nucleotide percentage (\%) in intron region of partial DNA sequences of Meisal gene on seven cassava genotypes calculated using Tamura \& Nei (1993) model.

\begin{tabular}{lcccc}
\hline $\begin{array}{l}\text { Cassava } \\
\text { genotypes }\end{array}$ & $\mathrm{T}(\mathrm{U})$ & $\mathrm{C}$ & $\mathrm{A}$ & $\mathrm{G}$ \\
\hline Roti & 31.1 & 17.1 & 38.3 & 13.5 \\
Variegata & 29.4 & 16.6 & 39.6 & 14.5 \\
Sayur & 29.9 & 17.1 & 39.3 & 13.7 \\
Hijau & 30.5 & 18.1 & 37.8 & 13.6 \\
Keriting & 29.6 & 17.1 & 39.2 & 14.1 \\
Lurus & 29.6 & 17.1 & 39.2 & 14.1 \\
Menggalo & 29.3 & 18.1 & 38.7 & 13.8 \\
\hline Average & 29.9 & 17.3 & 38.9 & 13.9
\end{tabular}

Intron region is not an encoding protein like exons; however many important protein binding sites are located in intron region, for instance, binding site for a protein of enhancer, silencer, splicesome, and other regulatory proteins. Those binding sites affect gene expression level; thus, the mutation in these sequences will affect the transcription level or sometimes the gene function. In addition, intron-containing sequences that are not the regulator protein binding sites and mutation in these sequences only cause the genetic variability in and between species (Griffith et al. 2008; Lomelin et al. 2010).

The genetic distance average between seven cassava genotypes observed was about $0 \%$ $11 \%$ (Table 4 ). The smallest genetic distance $(0 \%)$ was found in between Keriting and Lurus cassavas which showed that both cassavas had the same nucleotide sequences in partial DNA region of Meisal gene observed. It could be like that because Lurus cassava was shoot segregating from Keriting cassava.

Keriting is cassava genotype which has wavy and curly leaves and three or more branches. In addition to the curly leaves, it could also produce normal or straight leaves like common leaves in cassava plants (Figure 3). If the branch of Keriting cassava producing normal leaves is planted and grown up to be a plant, all leaves are normal and there are no cruel leaves. The plant is called Lurus cassava genotype (Roslim et al. 2015a). The tuber taste of Lurus cassava is as bitter as the tuber taste of Keriting cassava and both contain very high cyanide level in the fresh tuber that is approximately $400 \mathrm{ppm} /$ tuber fresh weight (Roslim et al. 2016).

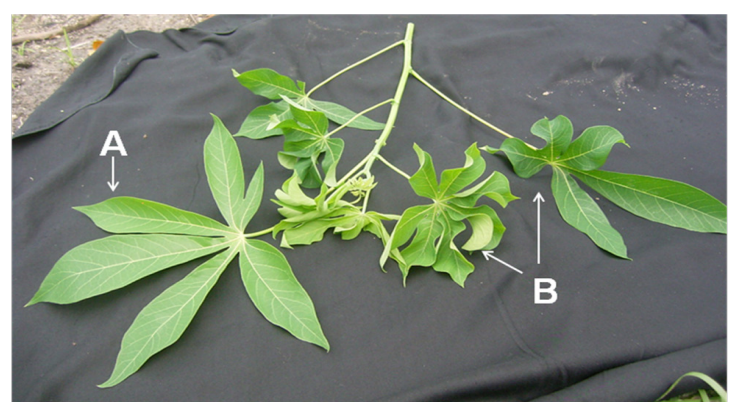

Figure 3. The stem of Keriting cassava plant producing (A) straight or normal and (B) curly leaves.

The farthest genetic distance (11\%) was between Sayur and Hijau cassava which had the same tuber taste that were not bitter and both

Table 4. Genetic distance matrix between seven cassava genotypes calculated using UPGMA method.

\begin{tabular}{lccccccc}
\hline Genotypes & Variegata & Roti & Sayur & Hijau & Keriting & Lurus & Menggalo \\
\hline Variegata & 0.00 & & & & & & \\
Roti & 0.04 & 0.00 & & & & & \\
Sayur & 0.07 & 0.07 & 0.00 & & & & \\
Hijau & 0.09 & 0.09 & 0.11 & 0.00 & & & \\
Keriting & 0.02 & 0.03 & 0.05 & 0.07 & 0.00 & & \\
Lurus & 0.02 & 0.03 & 0.05 & 0.07 & 0.00 & 0.00 & \\
Menggalo & 0.06 & 0.07 & 0.09 & 0.04 & 0.05 & 0.05 & 0.00 \\
\hline
\end{tabular}


being classified as sweet cassava genotypes. On the other hand, Variegata and Roti cassavas which were grouped as sweet cassava genotypes had the closer genetic distance with Keriting and Lurus cassava genotypes than with Sayur and Hijau cassava genotypes (Figure 4).

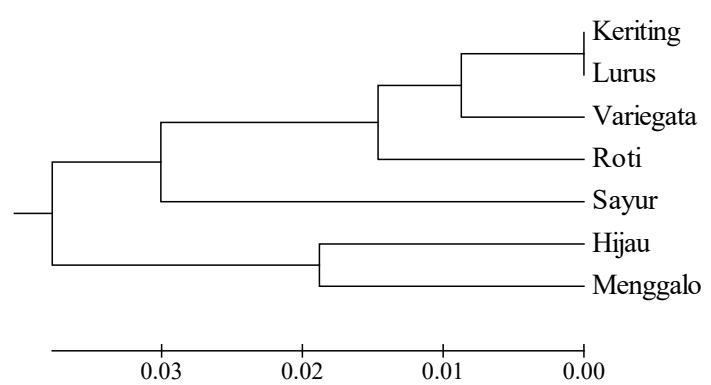

Figure 4. Dendrogram between seven cassava genotypes based on genetic distance calculating with UPGMA method.

The results showed that mutation or variation of partial DNA sequences of Meisal gene occurring in intron was unable to differentiate seven cassava genotypes into two groups separately each other based on the same tuber taste. It was suggested that mutation or variation detected in intron region did not occur in the regulator protein binding sites and thus did not affect the structure and function of isoamylasel enzyme translated. Lomelin et al. (2010) reported that mutation in the intron region of a gene was unable to affect the structure and function of the gene product, and the variation only became a genetic background of the organism.

\section{CONCLUSION}

Partial DNA sequences of Meisal gene on seven cassava genotypes observed was varied in intron region. The variation was caused by the transition (35.39\%) and transversion (64.61\%) substitution mutations. The genetic distance range between seven cassava genotypes was about $0 \%$ to $11 \%$. The variation in partial DNA sequences of Meisal gene which occurred in intron region was unable to differentiate seven cassava genotypes into two groups separately based on the tuber taste. The variation only became a genetic background for those cassavas observed.

\section{ACKNOWLEDGMENTS}

The research was funded by a grant from the Directorate of Research and Community Services, Ministry of Research, Technology, and Higher Education, the Republic of Indonesia un- der the Fundamental Research Program (Contract number: 518/UN.19.5.1.3/LT/2015) on behalf of Dr. Dewi Indriyani Roslim. We would like to express our grateful thanks to Dr. Marzuki, M.Ed., MA, lecturer of English Department, Faculty of Education, University of Riau for his writing assistance for this manuscript.

\section{REFERENCES}

Altschul, S. F., Madden, T. L., Schaffer, A. A., Zhang, J., Zhang, Z., Miller, W., Lipman, D. J. (1997). Gapped BLAST and PSI-BLAST: a new generation of protein database search programs. Nucleic Acid Res, 25(17), 3389-3402.

Amit, M., Donyo, M., Hollander, D., Goren, A., Kim, E., Gelfman, S., Lev-Maor, G., Burstein, D., Schwartz, S., Postolsky, B., Pupko, T., \& Ast, G. (2012). Differential GC content between exons and introns establishes distinct strategies of splice-site recognition. Cell Rep, 1(5), 543-556.

Beyene, D., Baguma, Y., Mukasa, S. B., Sun, C., Jansson, C. (2010). Characterization and role of isoamylase1 (Meisal) gene in cassava. Afr Crop Sci $J, 18(1), 1-8$.

El-Sharkawy, M. A. (1993). Drought-tolerant cassava for Africa, Asia, and Latin America. BioScience, 43(7), 441-451.

El-Sharkawy, M. A. (2003). Cassava biology and physiology. Plant Mol Biol, 53(5), 621-641.

Fassler, J. \& Cooper, P. (2008). BLAST Help. Bethesda (MD): National Center for Biotechnology Information (US).

Graur, D. (2003). Single-base mutation. Natur Encyclopedia of The Human Genome, 287-290.

Griffiths, A. J. F., Wessler, S. R., Caroll, S. B., Doebley, J. (2008). Introduction to Genetic Analysis $10^{\text {th }}$. New York: WH Freeman \& Company.

Han, Y., Gasic, K., Sun, F., Xu, M., Korban, S. S. (2007). A gene encoding starch branching enzyme I (SBEI) in apple (Malus x domestica, Rosaceae) and its phylogenetic relationship to Sbe genes from other angiosperms. Mol Phylogenet Evol, 43(3), 852-863.

Hannah, L. C. \& James, M. (2008). The complexities of starch biosynthesis in cereal endosperms. Curr Opin Biotechnol, 19(2), 160-165.

Howeler, R. (2006). Cassava in Asia: trends in cassava production, processing and marketing. In: Workshop on "Partnership in Modern Science to Develop a Strong Cassava Commercial Sector in Africa and Appropriate Varieties by 2020", May 2-6, 2006, Bellagio, Italy. CIAT, Bangkok. pp. 1-38.

Irtwange, S. V. \& Achimba, O. (2009). Effect of fermentation on the quality of gari. Curr Res J Biol Sci, 1(3), 150-154.

Jennings, D. L. \& Iglesias, C. (2002). Breeding for crop improvement. In: R.J. Hillocks, J.M. Thresh, and A.C. Bellotti (eds). Cassava: Biology, Production, and Utilization. CAB International Publishing. p. 149-166. 
Kang, G. Z., Liu, G. Q., Xu, W., Zhu, Y. J., Wang, C. Y., Ling, H. Q., Guo, T. C. (2013). Identification of the isoamylase 3 gene in common wheat and its expression profile during the grain-filling period. Genet Mol Res, 12(4), 4264-4275.

Keeling, P. L. \& Myers, A. M. (2010). Biochemistry and genetics of starch synthesis. Annu Rev Food Sci Technol, 1, 271-303.

Kim, S. H., Hamada, T., Otani, M., Takiko, S. (2005). Cloning and characterization of Sweetpotato isoamylase gene (IbIsa1) isolated from tuberous root. Breeding Science, 55(4), 453-458.

Lancaster, P. A. \& Brooks, J. E. (1983). Cassava leaves as human food. Econ Bot, 37(3), 331-348.

Lee, S. V. \& Bahaman, A. R. (2010). Modified gel preparation for distinct DNA fragment analysis in agarose gel electrophoresis. Tropical Biomedicine, 27(2), 351-354.

Lomelin, D., Jorgenson, E., Risch, N. (2010). Human genetic variation recognizes functional elements in noncoding sequence. Genome Research, 20(3), 311-319.

Marx, S. \& Nquma, T. Y. (2013). Cassava as feedstock for ethanol production in South Africa. Afr $J$ Biotechnol, 12(31), 4975-4983.

McMahon, J., White, W., Sayre, R.T. (1995). Cyanogenesis in cassava (Manihot esculenta Crantz). $J$ Exp Bot, 46(7), 731-741.

Mohamed, M. A. H., Alsadon, A. A., \& Al Mohaidib, M. S. (2010). Corn and potato starch as an agar alternative for Solanum tuberosum micropropagation. African Journal of Biotechnology, 9(1), 9199-9203.

Nakamura, Y., Umemoto, T., Takahata, Y., Komae, K., Amano, E., Satoh, H. (1996). Changes in structure of starch and enzyme activities affected by sugary mutations in developing rice endosperm. Possible role of starch debranching enzyme in amylopectin biosynthesis. Plant Physiol, 97(3), 491-498.

Nassar, N. \& Ortiz, R. (2010). Breeding cassava. Sci $A m, 302(5), 78-84$.

Nugraha, F., Roslim, D. I., Ardilla, Y. P. \& Herman. (2014). Analisis Sebagian Sekuen Gen Ferritin2 pada Padi (Oryza sativa L.) Indragiri Hilir, Riau. Biosaintifika: Journal of Biology \& Biology Education, 6(2), 70-79.

Nuwamanya, E., Baguma, Y., Kawuki, R. S., Rubaihayo, P. R. (2009). Quantification of starch physicochemical characteristics in cassava segregating population. Afr Crop Sci J, 16(3), 191-202.

Patron, N. J. \& Keeling, P. J. (2005). Common evolutionary origin of starch biosynthetic enzymes in green and red algae. $J$ of Phycology, 41(6), 1131-1141.

Roslim, D. I., Herman, Sofyanti, N. (2015a). Plasma Nutfah Ubi Kayu di Provinsi Riau. Pekanbaru: UR Press.

Roslim, D. I., Sanjaya, S. I., Herman. (2015b). Anali- sis keanekaragaman genetik ubi kayu (Manihot esculenta Crantz) varietas manis dan pahit berdasarkan sekuen DNA parsial dari gen Meisal. Makalah Seminar Nasional PERHIMPI Riau, 30 Maret 2015. Pekanbaru: Universitas Islam Riau.

Roslim, D. I., Herman, Sofyanti, N., Chaniago, M., Restiani, R., Novita, L. (2016). Characteristics of 22 cassavas (Manihot esculenta L., Crantz) from Riau Province, Indonesia. SABRAO J Breed Genet. in press.

Saghai-Maroof, M. A., Solimah, K. M., Jorgensen, R. A., Allard, R. W. (1984). Ribosomal DNA spacer length polymorphisme in barley: Mendelian inheritance, chromosomal location and population dynamics. Proc Natl Acad Sci, 81(24), 8014-8018.

Scott, G. L., Best, R., Rosegrant, M., Bokanga, M. (2002). Roots and tubers in the global food system: A vision. Statement to the Year 2020. The International Potato Center, Centro Internacional de Agricultura Tropical (CIAT), International Food Policy Research Institute (IFPRI), International Institute of Tropical Agriculture (IITA), and International Plant Genetic Resources Institute (IPGRI), Lima, Peru.

Sun, C., Ahlandsberg, S., Jansson, C. (1999). Analysis of isoamylase gene activity in wildbarely indicate its involvement in starch synthesis. Plant Molecular Biology, 40, 431-443.

Sundberg, M., Pfister, B., Fulton, D., Bischof, S., Delatte, T., Eicke, S., Stettler, M., Smith, S. M., Streb, S., Zeeman, S. C. (2013). The heteromultimeric devranching enzyme involved in starch synthesis in Arabidopsis requires both isoamylase1 and isoamylase2 subunits for complex stability and activity. Plos One, 8(9), e75223.

Takashima, Y., Senoura, T., Yoshizaki, T. (2007). Differential chain-length specificities twoisoamylase type starch-debranching enzymes from developing seeds of kidney bean. Bioscience Biotechnology and Biochemistry, 71(9), 2308-2312.

Tamura, K. \& Nei, M. (1993). Estimation of the number of nucleotide substitutions in the control region of mitochondrial DNA in humans and chimpanzees. Mol Biol Evol, 10(3), 512-526.

Tonukari, N. J. (2004). Cassava and the future of starch. Electron J Biotechno, 7(1), 5-8.

Valdez, H. A., Busi, M. V., Wayllace, N. Z., Parisi, G., Ugalde, R. A., Gomez-casati, D. F. (2008). Role of the N-Terminal starch-binding domains in the kinetic properties of Starch Synthase III from Arabidopsis thaliana. Biochemistry, 47(9), 3026-3032.

Wilson, W. M. \& Dufour, D. L. (2002). Why "bitter" cassava? The productivity of "bitter" and "sweet" cassava in a Tukanoan Indian settlement in the Northwest Amazon. Econ Bot, 56(1), 49-57. 